Пер Јакобсен

Универзитет у Копенхагену

e-mail:kv364@newmail.dk
821.163.41.09 Андрић И. https://doi.org/10.18485/ai_lik.2020.6.10.1

Оригинални научни рад

\title{
ИВО АНДРИЋ
}

У раду се обрађују три врсте текста Иве Андрића, односно, хроника, мити и истоториоррафија. Андрићев роман Проклетиа авлија суштински је мит, док На Дрини ћуйрија, према свеобухватном квалитету, представља хронику. Како то и са̂м наслов сугерише, Травничка хроника може се сматрати хроником, али, по својој општој структури, она је далеко сложенија и, поред својих хронолошких делова, испољава снажне особине психолошког романа, мита и историографије. Сваки од три травничка везира представљају по један историјски период Османског царства.

Кључне речи: Иво Андрић, типови текста, Проклете $а$ авлија, Травничка хроника, На Дрини ћуйрија, травнички везири.

Босна је присутна у Андрићевом стваралаштву као симбол подељености и разграничености. Ја ћу овом приликом говорити о три његова дела: На Дрини Ћуйрија и Травничкој хроници које су, као што је познато, написане током Другог светског рата, у време када се чинило да ће се границе Европе поново мењати. Такође ћу говорити о Проклетиој авлији која је објављена 1954. године.

На Дрини ћуйрија садржи опис живота једне мале заједнице који је сачинио „објективни” и удаљени хроничар.

Хроника је, у суштини, прилично једноставна врста текста. Њена најосновнија одлика јесте хронолошко низање догађаја тј. начин повезивања који највише одговара току догађаја у стварности. Налазимо ову врсту саопштења у најдоследнијем виду у аналима старог и средњег века који су набрајали догађаје из године у годину. Једноставност хронике заједно са њеним дидактичким и поучним могућностима 
одговарала је раним књижевним потребама Европе. Стога је хроника имала значајну улогу у стварању националних књижевности. Међутим, њена сврха или циљ - а то важи и за књижевну хронику - није казивање о томе како је свет уређен или откривање суштине одређене културе или цивилизације. Хроника, дакле, не пружа тумачење света. Она је реалистична и не служи се симболима, а као књижевну врсту одликују је недостатак главног заплета и психолошки портрети главних личности.

Иво Андрић је без сумње најизразитији представник књижевне хроничарске прозе и роман $\mathbf{H a}$ Дрини ћуприја представља најузорнији пример књижевне хронике. На Дрини ћуйрија се састоји од низа догађаја и епизода у прецизном временском редоследу. Стално нам је саопштено где се налазимо на временској осовини. Ради се о ономе што са̂м Андрић назива „стварни, стварно и заувек утврђени ток догађаја“. Нема главних јунака у његовој хроници, нема јединствене радње, догађаји представљају колективно искуство и памћење мале људске заједнице на обали Дрине. Андрићева свест о хроници се најбоље огледа у причи о Хусеину, неуспелом хроничару Вишеграда:

У ствари та хроника није била ни опширна ни опасна. 3а пет-шест година откад је мудерис води, она је испунила свега четири странице једне мале свеске. Јер, већину касабајлијских догађаја мудерис није сматрао довољно важним ни достојнима да уђу у његову хронику, због тога је она остала тако неплодна, сува и штура као охола уседелица. ${ }^{1}$

И када је хроника опет споменута, двадесет година касније, Андрић је задржао своју иронију према Хусеиновој селективној методи: „... а његова хроника наше касабе порасла је у ових двадесет година свега још за четири даље странице, јер мудерис што бива старији то све цени себе и своју хронику, а све мање догађаје око себе.“

1 NDĆ str. 153 (Svi citati su iz Sabrana djela Ive Andrića; Udruženi izdavači, Sarajevo 1981.) 
И у причи Аникина времена из 1939. год. се налази опис, у којем писац нам ставља до знања шта одликује хроника:

У књигама и списима преосталим из Мула Мехмеда било је и неколико пожутелих свешчица у које је он некад записивао све што се дешавало у касаби и што је чуо да се дешава у свету. Ту су биле записане поплаве, неродице, ратови ближи и далеки, помрачења Сунца и Месеца, чудесни небески знаци и прилике, и све што је у то време узбуђивало касабу и свет у њој. Поред вести да се у једном граду у Немачкој родио ђаво и да су га затворили у боцу, пошто није био већи од педља, и да многи свет долази да га гледа, била је вест о једном хришћанском генералу по имену Бунапарти, који је прешао у Мисир у безумној намери да ратује са султаном. ${ }^{2}$

У Травничкој хроници, пак, наћи ћемо три одломка који се имплицитно баве историјом османлијског царства. Историја свих великих царстава пролази кроз три фазе: 1) период раста и експанзије, 2) период врхунца моћи и 3) период слабљења и пропадања. Ово је важило за средњоисточна царства, за римско царство, за османлијско царство те у нашем модерном времену и за Хабзбуршко царство. Андрић, који се у свом делу као мало ко други бавио историјом Босне, очигледно дели ово схватање. У описивању три везира у Травнику може да се огледа ово схватање историјског тока османлијског царства.

Као што је познато, Травничка хроника, за разлику од романа На Дрини ћуйрија, обухвата временски кратак период: тек седам година, од 1807. до 1814. За то време, међутим, упознајемо чак три везира: 1) Хусреф Мехмед-паша, 2) Ибрахим-паша и 3) Али-паша.

2 Ivo Andrić, Sabrana djela VII, Sarajevo, str. 24-25. 
Историчари сматрају 14. и 15. век периодом експанзије (турског) царства. Ефикасна војска, чије је језгро чинила коњица, била је услов за ову експанзију. Остале делове војске сачињавали су у великој мери војници, хришћани са Балкана, који се нису преобратили у ислам. У првој фази овог периода царство су сачињавали локални владари који су прихватали султана као свог врховног владара, плаћали годишњи данак и обезбеђивали трупе за војску. Овим локалним владарима и њиховим поданицима било је гарантовано да ће њихове особености, традиције и религија бити признате и поштоване под османлијском владавином. Ова политика омогућила је Османлијама да владају удаљеним крајевима без гломазног административног апарата. Становници потчињених територија, чак и робови, могли су да стекну високе чинове и утицајне положаје у османлијском друштву. Тако важна и значајна војна и политичка институција као што су мамелуци, заснована на људима ропског порекла, постала је тежиште османлијске владавине.

Благост у поступању према робовима, које је препоручивао ислам, несумњиво помаже у објашњавању друштвене, националне и верске толеранције овог периода, Из Андрићеве дисертације о Развоју gуховної животиа у Босни йоg уйицајем йурске влаgавине сазнајемо да присилна исламизација није била политика царства у време када је Босна заузета у другој половини 15. века, премда је оваква политика била резултат политичке и војне стратегије, пре него мудрости и толеранције.

У првом периоду, у другој половини 15. века, када је Босна освојена, може се уочити постојање европског утицаја на османлијски политички и културни живот, утицаја који је проузроковао оштре реакције у следећем 16. веку.

Први везир у Травнику био је Хусреф Мехмед-паша. Када га представља на почетку хронике, Андрић за њега каже: „Из Египта је довео одред од тридесетак оданих мамелука са којима је волео да изводи вежбе на травничком пољу."

Овом кратком реченицом обавештени смо не само о Мехмед-пашиној посвећености ратовању и ратничким занимањима, већ и о његовој тесној вези са мамелучким 
системом; касније се каже, такође експлицитно, да је он, као и мамелуци, првобитно био пореклом роб. Он је из Грузије, тј. из оног дела царства који је близу османлијске постојбине пре заузимања Анадолије. Мехмед-паша је тако представник изворне османлијске владавине. Он је пре свега ратник и као такав описан је као „храбар”, „бистар”, „лукав”. И када француски конзул Давил хоће да угоди везиру за време њихових разговора, он се неминовно окреће везировим омиљеним темама као што су пловидба и ратовање на мору:

У својој најскровитијој дубини, везир је гајио жељу да једног дана буде наследник свога великог господара Кучук Хусеин-паше и да као капудан-паша настави његове планове и замисли на подизању турске ратне морнарице. ${ }^{3}$

Директна алузија на важност коју је коњица имала у османлијској ратној вештини учињена је у помињању Мехмед-пашине ергеле: „Више од самих мамелука дивљење је изазивала везирова ергела, дотад невиђена у Босни и по броју и по вредности коња.“

Толеранција првог периода одражава се у личности Мехмед-паше. Он је, да тако кажемо, описан споља помоћу мноштва придева и именичких израза. За њега се наравно не каже да је толерантан, али придеви употребљени у неговом опису иначе могли би да послуже као карактеристике, или чак као синоними толеранције. Њега аутор дефинише као „разумног“, „љубазног“, „отвореног“, „живог“, „оптимистичног“, живахног“ и „љубопитљивог“. Мехмед-пашина још изразитија особина јесте његово дивљење према Француској, земљи која се често помиње као оличење Европе. У сваком случају, много је пута наглашено да Мехмед-паша не држи много до османлијског начина живота и до Оријента.

Тако откривамо најмање три особине у опису Мехмедпаше које га повезују са првом фазом Османлијског царства: посвећеност ратовању, толеранција и отвореност према Европи. 
Значај ових особина потенцирају у нарацији јасно наглашене супротности између њега и његовог наследника, које такође налазимо када поредимо први и други период царства.

Напоредо са концентрисањем власти у рукама једног човека у другом периоду царства, изграђена је велика и гломазна централна администрација. Индикативно је да је први државни буџет састављен за време Бајазита и да је исти тај Бајазит подстакао реакцију против европског утицаја који је био прилично јак током претходне половине столећа. Турски језик и муслимански обичаји били су ојачани.

Релативно толерантно друштво претходних векова замењено је муслиманским и бирократским режимом који се састојао од султана као апсолутног владара. Овај режим представља Ибрахим-паша, други везир у Травнику.

Уочљива је мера којом се наглашава разлика између Ибрахим-паше и његовог претходника. Не само да Андрић употребљава израз налик на формулу кад га први пут помене, кад каже да је Ибрахим-паша био „сушта противност Мехмед-паше“, већ он такође прави контраст између ова два човека користећи се доследним антонимима. У опису Мехмед-паше истиче се да је он „био за једног оријенталца, необично жив, љубазан и отворен“ и да „ничег од оног непомичног османлијског достојанства није било на њему“, а када упознамо Ибрахим-пашу неких 150 страница касније, читамо: „Уместо пред младим, живим и пријазним Ђурђијанцем, Давил се на Дивану нашао пред тешким, непомичним и хладним Османлијом“.

Нису, међутим, само везири различити, већ је експлицитно дата и разлика између њихових домова и људи који их окружују:

Као што између два везира није било никакве сличности, тако су и њихови сарадници били потпуно различити. Људи које је Мехмед-паша довео и одвео са собом били су углавном у млађим годинама, сви мање или више из војничких позива, у сваком случају сви добри јахачи и ловци [...] Ибрахим-пашина кућа била је 
сасвим друге врсте. Ту је било и више света по броју и разноличнијег по карактера и изгледу. ${ }^{4}$

Ибрахим-пашину кућу, детаљно описану кроз скоро читаво IX поглавље, као и у другим одељцима расутим у нарацији, сачињавају не само особе које имају јасно одређену функцију чиновника, већ исто тако и чудни ликови чије су дужности нејасне и загонетне. Ова, дакле, чудна кућа представља паралелу гломазној бирократској државној администрацији која се развила у време када је Османлијско царство било на врхунцу своје моћи.

Симболична представа османлијске државе налази се у опису Ибрахим-паше као особе где главом, што је позната метафора за владара, доминира каук, док је остали део тела, огромни државни апарат, аморфан и потпуно непробојан.

У везира је било широко, бескрвно лице, пресавијено у неколико малобројних, али дубоких бора, са ретком брадом која је опет на свој начин била без боје, као давно мртва трава, полегла и избледела у шкриповима на литици. То лице је одударало чудно од огромног каука који му је био набијен до обрва и преко ушију [...]. И тај каук је на његовој глави стрчао чудно као да га је туђа рука поставила у мраку и отприлике, на мртвацу који га неће никад више померати ни скидати, јер је одређен да са њим буде сахрањен и иструне. Све остало на томе човеку, од врата па до земље, било је један једини блок у ком је тешко разликовати руке, ноге и струк. Није се могло проценити какво је то тело које живи под хрпом одела од чоје, коже, свиле, сребре и гајтана. Оно је могло да буде ситно и слабо али исто тако и снажно и велико. И што је најчудније, та тешка маса одеће и накита имала je, у ретким тренуцима кад се кретала, неке неочекивано брзе и снажне покрете млађег нервозног човека. А за то време је велико, престарело и обамрло лице остајало непокретно и безизразно. Изгледало је као да је тај мртвачки лик и круту гомилу одела покрећу изнутра невидљива пера и опруге. ${ }^{5}$ 
О слабљењу и пропасти Османлијског царства и о трећем везиру у Травнику нема много шта да се каже. Трећи везир, Али-паша симбол је трећег периода режима који једва да интересује Андрића. Али-Паша је већ на почетку описан као бруталан човек и насилник:

Нови везир је долазио без неког чиновничког особља, без ичоглана и харема, сам и го као хајдук у шуми али са хиљаду и две стотине добро оружаних Арнаута опасног изгледа и два велика пољска топа, а пред њим је ишао глас неурачунљивог крволока и најсвирепијег везира у Царевини. ${ }^{6}$

Без чиновника и дворских службеника, тих незаменљивих атрибута државе, већ, како је речено, „сам и го као хајдук у шуми“, као чисто, слепо насиље. Један од кратких одељака о везиру описује терор као систем владавине и његов утицај не само на жртве, већ и на саме владаре. Овај процес распадања доспео је до тачке када је „Источно питање“ било непрекидно на дневном реду европских конференција, и када је синтагма „болесник са Босфора“ постала одредница за некада моћно царство. Подсетићемо се овог израза поново на крају романа, када везир прима Давила последњи пут. Иако се не помиње никакав други узрок болести осим дејства страха на самог силника, јасно и веома убедљиво се, међутим, каже: „Али-паша је сада имао изглед болесног човека.“

Као Вишеград, и Травник је вековима живео у „слаткој тишини турских времена”, све док бурни историјски и политички догађаји почетком 19. века нису одједном начинили од ове вароши место сусрета европских сила и Турске, када су Наполеонова Француска, а за њом Аустрија послале своје конзуле са намером да политички и трговински искористе присуство у Босни.

Посматрати Травничку хронику као хронику, онако како наслов сугерише, несумњиво је привлачна помисао, али пре тога ваљало би да се сетимо карактеристике које одликују књижевну хронику. У том смислу Травничка хроника се не 
подудара са хроником. Показује јасне одлике како психолошког романа тако и историје и мита, које су по много чему у директној супротности са хроником.

Оно што се одмах уочава јесте да је Травничка хроника, за разлику од хронике о Вишеграду, роман са главним ликом. Приповедање почиње са доласком француског конзула Давила у Травник и завршава се његовим одласком из града, осам година касније. Он је једини француски конзул у Травнику, а за противнике има два аустријска конзула и три турска везира. Давил се јавља у свим поглављима књиге, и за разлику од осталих ликова, његов опис је дат подробно и са пуно психолошких детаља. У том психолошком описивању Давиловог лика, приповедач је у више наврата принуђен да напушта време и простор хронике да би објаснио доживљаје који су имали одлучујући утицај на Давила и који покрећу његове реакције према другим ликовима или према Оријенту, који упознајемо пре свега кроз његово виђење. Ова психолошка мотивација не поклапа се са хроником, а временски и просторни скокови представљају суштински раскид да сукцесивним редоследом догађаја. То не значи да велики делови Травничке хронике нису сагласни са концептом времена у хроници, али уз линеарни и прогресивни ток времена, изнова се сусрећемо са чисто митском концепцијом. То се може видети у релативно снажном истицању годишњих доба као циклусног времена, при чему је пролеће апострофирано као животна снага, дубоко повезана са младошћу и непролазношћу:

Пролеће поравњава и поправља све. Док земља цвате, увек поново и поново, и док има људи да тај феномен посматрају и уживају у њему, све је добро.

А људи ће бити увек, јер се непрестано губе они који више не могу и не умеју да виде сунце и цвеће, а пристижу нови. Како каже песник: „У деци се обнавља и чисти река човечанства." 
Као што је већ поменуто, хроника не тумачи свет тј. не бави се његовом почетком ни крајем, нити покушава кроз симболе да објасни или да представи његово устројство. У поетским интерпретацијама мита, готово увек наилазимо на снажно истакнут дуализам. То могу бити библијске легенде о стварању света или борба добра против зла у нордијским митовима о крају света. Митови могу да објасне природне феномене, конфликт између живота и смрти, светла и мрака како знамо из дугачког низа оријенталних, грчких или нордијских митова. Време и простор су небитни у миту. Догађаји у миту нису повезани са одређеним временом или простором. Митови важе увек и свуда.

Многи од митова могу такође да се интерпретирају као сукоби између култура са два супротстављена културна круга: земљорадник Авељ против сточара Каина, ловац Исав против сељака Јакова.

У основи своје тематске структуре, Травничка хроника је роман изграђен на дихотомијама. Културолошка дихотомија између Истока и Запада, толико уочљива и значајна у роману, само је један у брижљиво осмишљеном системом контраста, и може се посматрати на три различита нивоа. На најопштијем нивоу налазимо такве контрасте као што су живот - смрт, светлост - тама, здравље - болест, раст опадање, младост - зрелост.

На другом, мање општем нивоу, који бисмо назвали цивилизацијским и који обухвата најбитнију опозицију Исток - Запад, наилазимо на контрасте између француског и аустријског конзулата. Систем цивилизациских опозиција је тако помно разрађен, да се на пр. ликови из француске колоније врло често сучељавају одређеним ликовима из аустријске. Тако је Давил супротстављен аустријском конзулу фон Митереру, француски преводилац Давна Аустријанцу Роти, госпођа Давил госпођи фон Митерер итд.

На трећем нивоу, налазимо личне и психолошке контрасте, често дефинисане и описане само управо и само тако, као противност или супротност: „Сушта противност Тахирбегова и његов непомирљив и немоћни противник био 
је хазнадар Баки”. У овом систему контраста, један исти пар опонената може се суочити на сва три нивоа. Сукоб између конзула Давила и његовог младог канцелара Дефосеа може послужити као пример. Они су ван сваке сумње супарници: „Овај млади Француз у овој пустињи и његов истински сарадник, толико је у свему друкчији од њега, да се Давилу чинило на махове да живи поред странца и непријатеља." Ова два човека супротстављена су један другом у дихотомији младост - зрелост која припада општем нивоу. На нижем културолошким нивоу, Давил и Дефосе се супротстављају један другом у ставовима и односима према револуцији, Наполеону и бројним државним институцијама, а на најнижем, индивидуалном нивоу, Давил је несигуран, неодлучан, сентименталан, док је Дефосе пун самопоуздања, одлучан, отворен, директан.

Са друге стране Давил и Дефосе, заједно са осталима у француском конзулату, супротстављени су Аустријанцима, али два конзулата чине нешто што би се могло назвати „западни свет у сукобу са Оријентом”. Међутим, баш као што појам „Запад” није једнозначан, тако није ни „Исток”. Исток није само отоманска цивилизација, оличена у везирима и њиховој резиденцији „Конаку”, већ и народ Босне са својом колективом психологијом.

А све се своди на једно: подељеност на два света која је отворено изражена код „илирског доктора” Колоње када говори о Босни и о људима који се налазе на средини те подељености:

На њих се могу применити речи које је пре шест векова написао велики Џелаледин, Џелаледин Руми: „Јер самог себе не могу да познам. Нити сам хришћанин, ни Јеврејин, ни Парс, ни муслиман. Ни сам са Истока ни са Запада, ни са копна ни са мора” ... То су људи са границе, духовне и физичке, са црне и крваве линије која је услед неког тешког и апсурдног неспоразума потегнута између људи, божијих створења, између којих не треба и не сме да буде границе. То је она ивица између мора и копна, осуђена на вечити немир. То је трећи свет у који 
се слегло све проклетство услед подељености земље на два света. ${ }^{8}$

Митски слој Травничке хронике је убедљив, али најчистији пример мита налазимо ипак у Проклетиој авлији. О фра Петру који прича причу о Проклетој авлији наилазимо већ у уводу његове приче:

Причао је као човек за ког време нема више значења и који стога ни у туђем животу не придаје времену ни редовном току времена неку важност. Његова прича могла је да се прекида, наставља, понавља, да казује ствари унапред, да се враћа уназад, да се после свршетка допуњава, објашњава и шири, без обзира на место, време и стварни, стварно и заувек утврђени ток догађаја. ${ }^{9}$

Време и простор не играју никакву улогу, и не добијамо јасну представу где се та Проклета авлија налази. Чујемо, наравно, да се налази у Стариграду, а где се налази Стариград ако не на граници између Истока и Запада, на граници између два света.

Сам положај Проклете авлије био је чудан, као срачунат на мучење и веће страдање затвореника. Из Авлије се не види ништа од града ни од пристаништа и напуштеног арсенала на обали испод ње. Само небо, велико и немилосрдно у својој лепоти, у даљини нешто мало од зелене азијске обале с друге стране невидљивог мора, и тек понеки вршак непознате џамије и џиновског кипариса иза зида. Све неодређено, безимено, и туђе. ${ }^{10}$

„Тек понеки вршак непознате џамије и џиновског кипариса иза зида“, каже дакле Андрић. Џамија као симбол ислама

8 TH str. 330.

9 PA str. 12-13.

10 PA str. 22. 
и Оријента, и кипарис тј. чемпрес као симбол Медитерана и Запада и европске цивилизације. Разлика између Истока и Запада није могла лепше да се изрази!

А најјасније је дуализам изражен у причи о султану Бајазиду и његовом брату Џему који су се после смрти њиховог оца борили за турски престо. Конфликт између два брата у Проклейој авлији није само сукоб између две културе као сукоб између Каина и Авела. Бајазид представља оно што је продорно и активно насупрот пасивној, контемплативној и уметничкој природи његовог брата. То је сукоб између два темперамента. Чујемо више пута о овом сукобу. Први пут је то објективна и историјски коректна исповест о читавом току догађаја са тачним подацима о години и месту. Време и простор опет игра улогу - за час смо опет у историји или хроници. Повест о несрећном Џему улази у књигу зато што је један од затвореника, Ћамил, студирао његову историју и мало по мало се идентификује са Џемом - и у овом мењању идентитета прелазимо у мит. Хроника или историја о Џему испричана је у трећем лицу, а мит се доживљава кроз прво лице:

Фра Петар се није право ни сећао кад је у ствари почела та прича без реда и краја. Исто тако није одмах ни приметио тренутак, тешки и одлучни тренутак, у ком је Ћамил јасно и први пут са непосредног причања туђе судбине прешао на тон личне исповести и стао да говори у првом лицу. ${ }^{11}$

Можемо да гледамо на романе На Дрини ћуйрија, Травничка хроника и Проклейа авлија као на трилогију. Затвор у Цариграду, простор на коме се сусрећу нације и религије, поклапа се у свим кључним тачкама са Босном из Травничке хронике. Оба простора носе проклетство постојања између два сучељена света. У трећем делу трилогије, роману На Дрини ћуйрија, Босна носи улогу градитеља мостова и посредника између два света:

11 PA str. 
Када мелећи виђеше како људи не могу да пређу оне халуге и дубине ни да свршавају послове, него се муче и узалуд гледају и довикују с једне обале на другу, они изнад тих мјеста раширише крила и свијет стаде да прелази преко њихових крила. Тако људи научише од божјих мелећа како се граде ћуприје. Е зато је, послије чесме, највећи севап саградити ћуприју, и највећа грјехота дирати у њу, јер свака ћуприја, од оног брвна преко планинског потока па до ове Мехмед-пашине грађевине, има свог мелећа који је чува и држи, док јој је од Бога суђено да стоји. ${ }^{12}$

\section{Per Jacobsen}

\section{IVO ANDRIĆ}

The paper deals with three types of text in Ivo Andrić viz chronicle, myth and historiography. His novel Prokleta avlija is basically a myth, wheras Na Drini ćuprija, in its overall quality represents the chronicle. Travnička hronika may be regarded as a chronicle as the title suggests, but is in its general structure far more complex and shows, besides its chronological parts, also strong characteristics of psychological novel, myth and historiography. The three veziers of Travnik each represent a historical period of the Ottoman empire.

Key Words: Ivo Andrić, text types, "Damn Courtyard", "Travnik Chronikle", "Bridge on the Drina", Travnik viziers. 